\title{
TRADITIONS AND INNOVATIONS OF THE CONCEPT OF ADMINISTRATIVE LAW UNDER REFORM
}

\author{
Kateryna Holovko' ${ }^{1}$, Svitlana Levchenko²
}

\begin{abstract}
The article is devoted to the study of the essence and content of individual transformation processes in the field of administrative law of Ukraine under the conditions of administrative and legal reform. Attention focuses on the issue of a detailed assessment of the nature of public relations, which are included in the sphere of legal regulation of the field of administrative law. The author concludes that a qualitative and substantial update of the theoretical and methodological basis should be an integral part of administrative and legal reform. The importance of the process of updating the categorical framework, the introduction into the legal circulation of new categories, capable of creating a more solid scientific basis of administrative law, is proved. The positions of leading Ukrainian scholars in the field of administrative law on the essence of the category "public administration" are analysed and the reasons for the dualism of approaches to its definition in the Ukrainian administrative and legal doctrine are revealed. Attention is paid to the basic factors of the shift of the idea of the priority of the rule of law towards the specific relationship between public administration bodies and individuals. The subject matter of the study is the traditions and innovations of the concept of administrative law of Ukraine in terms of reform. The purpose is to study the nature and content of transformational changes in the administrative law of Ukraine at the present stage. The methodological basis of the study was the set of methods and techniques of scientific knowledge. The methodological construction is based on a systematic analysis that defined its directions. The systematic approach in some issues was supplemented by an axiological (ideological) approach. Empirical methods such as observation, description, comparison, and inductive generalization were used to identify trends in the reform of the administrative law of Ukraine. The logical and semantic method was used for formulation and in-depth study of the conceptual framework. The dialectical method of cognition made it possible to investigate the problems associated with the definition of the concept of "public administration" in Ukrainian administrative and legal doctrine. Application of methods of modelling, analysis, synthesis, generalization, and analogy allowed formulating the conclusions of the study. The conclusions of this study are that the author has established that an integral part of the administrative and legal reform of Ukraine should be a qualitative and substantial updating of the categorical and terminological framework of the field of administrative law and, above all, the basic category of "public administration". At the same time, in the context of Ukraine's development as a democratic and legal state, all reform initiatives must be systematic and consistent. Special attention also needs to be paid to scientific and analytical monitoring of the state of introduced changes and consequences of the implemented administrative reform measures, which will allow expeditiously identifying and correcting possible mistakes, as well as making recommendations on further prospects of the development of the administrative and legal sector. Practical implications. The results of the study will help to better understand the basic aspects of the new concept of administrative law and can be used in the research field for a further in-depth study of the issue of transformational changes in the administrative and legal field.
\end{abstract}

Key words: administrative law of Ukraine, administrative and legal reform, administrative reform, governance, state-centrism, institutional support, human-centrism, methods of administrative law, subject of administrative law, public administration.

JEL Classification: K19, K23, H76

\footnotetext{
Corresponding author:

${ }^{1}$ Black Sea Research Institute of Economy and Innovation, Ukraine.

E-mail: k.v.mozharovska@gmail.com

${ }^{2}$ Black Sea Research Institute of Economy and Innovation, Ukraine.

ORCID: https: //orcid.org/0000-0002-3386-5962

E-mail: lightstarpro@ukr.net
} 


\section{Introduction}

Transformation processes aimed primarily at global reform of all spheres and branches of public life have become objectively conditioned on the path of democratic transformations of Ukrainian society and the establishment of Ukraine as a powerful European state. In the context of integration processes, the need for systematic changes of the legal tools to solve national and global challenges, as well as to ensure the declared transformation processes, whose quality and compliance with the requirements of the times must become an essential feature, has also become urgent.

Emphasis should also be placed on the internal factor of Ukrainian systemic reforms caused by the rapid development of existing ones and the emergence of a large number of new, previously unregulated public relations, citizens' dissatisfaction with the quality of institutional support, diminished public confidence in state institutions and the authority of public bodies, the need for the orderliness, organization, and coherence of the development of state institutions in the context of European integration of Ukraine

At the same time, the basis of the legal arsenal of ensuring the announced systemic reforms is undoubtedly the rules of administrative law, which without special reservations can be recognized as the dominant ("title") industry in the processes of legal support for the implementation of the internal vector of public policy.

Despite the fact that an extensive galaxy of scholars and practitioners of the administrative branch studied the nature and content of transformational changes in the administrative law of Ukraine in the context of reform, including V. B. Averianov, V. M. Bevzenko, Yu. P. Bytiak, H. P. Bondarenko, I. P. Holosnichenko, Ye. V. Dodin, S. V. Kivalov, V. V. Kovalenko, L. V. Koval, T. O. Kolomoiets, Ye. V. Kurinnyi, R. S. Melnyk, M. S. Mikhrovska, S. H. Stetsenko, and others, at the present stage, many issues related to particular aspects of the reform of the administrative law of Ukraine have a high level of scientific novelty.

Therefore, the relevance of the issue of traditions and innovations of the concept of administrative law of Ukraine in the conditions of reformation, theoretical and practical significance of the chosen topic are not in doubt.

The purpose of the article is to investigate the essence and content of transformational changes in the field of administrative law of Ukraine at the present stage.

The methodological basis of the study was the set of methods and techniques of scientific knowledge. The methodological construction is based on a systematic analysis that defined its directions. The systematic approach in some issues was supplemented by an axiological (ideological) approach. Empirical methods such as observation, description, comparison, and inductive generalization were used to identify trends in the reform of the administrative law of Ukraine. The logical and semantic method was used for formulation and in-depth study of the conceptual framework. The dialectical method of cognition made it possible to investigate the problems associated with the definition of the concept of "public administration" in Ukrainian administrative and legal doctrine. Application of methods of modelling, analysis, synthesis, generalization, and analogy allowed formulating the conclusions of the study.

\section{Transformation of the concept}

There is no doubt that administrative law has a universal social role - to ensure the realization of various groups of public needs and interests in the basic (fundamental) spheres of public life, which is carried out by means of the functioning of an extensive system of state institutions. Which allows suggesting that the said industry holds a special and unique place among the fundamental branches of domestic law.

At the same time, with the proclamation of state independence, a new, modern, and effective model of the organization of state power was started, which could sufficiently satisfy the needs of the dynamic development of civil society, formation of a progressive socio-economic system and democratic rule of law. However, the state of administrative legislation, which substantially lags behind the requirements of the present, regulates public relations in a vague and contradictory manner, does not ensure the assertion of the priority of human rights and freedoms in its relations with the state (Kovalenko, 2012), the lack of demand for fullfledged administrative and legal instruments, as well as its inept and inefficient use, are still obstacles to the progressive social development, growth of the power of Ukraine, and realization of quite real possibilities of comprehensive positive self-realization of its citizens.

That is why, given the European vector of development of our country, it was extremely important to increase the institutional capacity of Ukraine, to rethink scientific and methodological principles of administrative law as a fundamental branch, to transform the content and system of existing administrative legislation in accordance with the needs of qualitative change of the role of administrative law in regulating the relationship between the state and citizens, to improve the efficiency of public administration in various spheres of public life, to promote the effective use of administrative law as the basis of legal support for administrative reform, undertaken in modern conditions (Averianov, 2002).

It should be noted that, exploring in its time the main directions of reforming administrative law, its role in regulating the relationship between the state and citizens, S. V. Kivalov (2003) noted that acting as an important tool for ensuring the implementation 
of the constitutional postulate, "human and citizen's rights and freedoms and their guarantees determine the content and orientation of the activity of the state," the public purpose of administrative law is constantly changing and determined based on a combination of the following tasks: regulation of the administrative activity of the executive and local self-government bodies; introduction and regulation of truly democratic relations between these bodies and citizens.

Therefore, it is not accidental at present to shift towards specific relationships between public administration and individuals the idea of the priority of the rule of law, which consists in the fact that the key characteristics should be not "managerial" but "law enforcement" (related to securing implementation of human rights and freedoms) and "protection" (related to the protection of violated rights) functions. Therefore, special attention needs to be given to the creation of proper conditions for the realization of human rights and freedoms, which is connected with the ongoing modernization of domestic administrative law under new, democratic principles (Andriiko, Nahrebelnyi, Kysil, Pedko, Derets, Pukhtetska and Kirmach, 2012).

At the same time, as S. H. Stetsenko (2007) notes, despite the change of the "state-centric" ideology to "human-centric" one, the priority of service to a person by the state (public service activity), public administration in the economic, socio-cultural, administrative and political spheres of society cannot be removed from the administrative law agenda. First of all, because of its importance as a phenomenon in public life.

And here is an indicative opinion of $\mathrm{K}$. Bondarenko (2016), which states that it should be about filling the category of "public administration" with new content, which can substantially change it so that governance corresponds to the human-centric concept of the state and administrative law as an area of public law, according to which the state declares the postulate of "the priority of realization of constitutional rights of citizens in legal relations with the public administration" regarding the leading role of public bodies.

\section{Creation of a new theoretical and methodological base}

However, it is necessary to fully agree with V. B. Averianov (2003), who states that a necessary condition for successful reform of administrative law as a fundamental branch of Ukrainian law is the creation of a new theoretical and methodological base of administrative law science.

It seems that by now it is necessary to give a more detailed assessment of the nature of social relations within the sphere of legal regulation of the administrative law (the common interpretation of which was formed in Soviet times as "law of public administration", "administrative law").
Considering the conceptual positions of the new doctrine of Ukrainian administrative law, it should be noted that the role of administrative law as a sector in the context of transformational changes has become not purely "administrative" but mainly "serving", "publicservice" (Averianov, 1998). At the same time, the administrative and public (social) value of administrative law was transformed - administrative law began to be considered as the main regulator of harmonious relations between public administration, entities (bodies and officials) of executive power and local selfgovernment and citizens (Averianov \& Pukhtetska, 2008). Therefore, in view of the reformatting of the main aspects and key characteristics of the said sector, it can be argued that the managerial nature of relations in the content of the subject of administrative law has ceased to be dominant, and the sphere of administrative relations has narrowed considerably. However, it should be noted that the meaning of the content in terms of the theoretical and legal characteristics of the category "public administration" in the context of practical activity of administrative bodies in Ukraine has not changed significantly.

In modern conditions of the transformational update of the content of the subject of administrative law, its methods also have changed. Thus, at present, the vast majority of special administrative law methods are dispositive, based on the ability to choose the behaviour and use of administrative discretion (e.g., method of coordination, administrative contract, incentive, investment, encouragement, registration).

The above allows concluding on changes in the path of democratic changes and integration processes of the very essence of administrative law as a branch (since the subject matter and method of legal regulation have undergone transformational changes).

At the same time, as regards the renewal of the categorical framework, the introduction into the legal circulation of new categories capable of creating a more solid scientific basis of administrative law. Thus, in the context of integration processes, the concepts of "administrative services", "public administration", "subject of public administration" and "public administering" are increasingly being found in the laws and regulations of Ukraine and domestic legal literature. However, it should be emphasized that, unfortunately, many recent definitions have not been implemented at the legislative level and have not been fully and thoroughly covered in the work of legal scholars. Herewith, the lack of a unified approach to defining the essence and content of the basic categories of modern administrative science, introduced as a result of administrative reform in Ukraine, can become a stumbling block in the orderliness, organization, and coherence of the development of state institutions in the context of European integration of Ukraine. 
For example, the presence of quite different modern scientific approaches to defining the essence and content of the category "public administration" causes difficulties in the process of forming a unified normatively balanced approach to the formation of the system of public administration entities in Ukraine, determining their status, a clear delineation of functions, range of powers, and boundaries of responsibility, which is another threat to the effective reform of the administrative law of Ukraine. Although the introduction of the "public administration" structure was carried out in 2001 (Hnydiuk, 2001), it was intended not only to make a symbiosis of concepts of "governance" and "local self-government" but also to give the said structure a qualitatively new content.

At the same time, the analysis of sustainable scientific developments, devoted to the concepts of "public administration" and "subject of public administration", makes it possible to state that the issue of developing a unified approach to determining their essence and content has not yet been resolved in the theoretical plane. In addition, according to some scholars, there are two (possibly more) approaches to defining the essence of public administration in modern legal science, because in European law there are two definitions of the concept of "public administration": narrow and broad (Hnydiuk, 2006).

The analysis of the provisions of the current legislation of Ukraine for the presence of legislative consolidation of these concepts also does not produce the expected results, although it allows to state that the current legislation of Ukraine actively uses these legal categories.

Turning to the achievements of V. B. Averianov (2003), we can conclude that public administration is a set of executive bodies and executive self-government bodies subordinate to political power, which enforce the law and perform other public-management functions.

A similar position is supported by N. P. Kamenska (2014), who interprets the notion of public administration as a system of executive and local selfgovernment bodies which, in accordance with the law and within the competence, administer public affairs.

"Narrow" approach in defining the concept of "public administration" is supported by S. S. Vitvitskyi (2016), D. O. Vlasenko (2017), I. B. Koliushko and V. P. Tymoshchuk (2005) and others.

M. S. Mikhrovska (2011) considers public administration the symbiosis of the system of bodies of executive power and local self-government. Herewith, according to the author, public administration is a collection of bodies of executive power and local selfgovernment, which are subordinated to public authority, whose activity is aimed at the law enforcement and the implementation of other public-management functions that may be delegated to enterprises, institutions, and organizations and any other subjects carrying out the functions of public administration, which by their activity ensure the rights and freedoms of man and citizen.
It should be noted that in the modern domestic administrative law literature, the position has recently become quite established that the structure "public administration" is indeed close in content to the structure of "governance" but does not completely coincide with it (Melnyk, 2014).

Considering the category of "public administration", V. K. Kolpakov notes that public administration is a system of organizational and structural entities that have legitimately acquired the powers to implement them in the public interest (2008). In further scientific research, the author substantiates the view that public administration as a legal category has two dimensions: functional and organizational-structural. At the same time, the functional dimension involves the consideration of public administration as the activity of relevant structural entities in the performance of functions aimed at the realization of public interest, and organizational and structural - the set of bodies formed for the implementation (realization) of public authority (Kolpakov, Kuzmenko, Pastukh, Sushchenko, 2012).

T. O. Karabin notes that the correct understanding of public administration is revealed only in the so-called organizational and structural aspect - as a collection of bodies and officials who exercise public authority through executive-administrative activity (Karabin, 2015).

In the legal literature, there are reasonably prevailing views on "public administration" as a system of state executive bodies and executive bodies of local selfgovernment, enterprises, institutions, organizations, and other entities vested with administrative and managerial functions acting for the purpose of securing the interests of both the state and society, as well as the totality of these administrative and managerial actions and measures established by law (Kravtsova \& Solonar, 2010).

Some scholars define public administration as a system of executive bodies and local self-government, enterprises, institutions and organizations in the case if executive authorities and local self-government bodies delegate them a part of their powers and any other entities that perform public-management functions, a set of organizational actions and measures taken by them within the limits set by the law, with the aim of achieving public interest and reliable protection of rights and freedoms of man and citizen (Bilozerska, 2007).

Other scientific views, in their essence, mainly go along with ideas regarding this issue.

This indicates that the domestic administrative-legal doctrine has formed several concepts of understanding of the concept of "public administration", which are sufficiently substantiated and convincing. Thus, in the narrow sense, public administration is a system of executive and local self-government bodies which, in accordance with the law and within the competence, administer public affairs. In the broad sense, public administration is the totality of executive bodies, local governments, and other entities that are empowered by 
law or administrative contract to perform functions in the public-law sphere (Tsvirkun, 2016).

It appears that the formation of a dualism of approaches to defining the concept of "public administration" in Ukrainian legal doctrine is associated, first of all, with the significant influence of European law, in which the said legal category is widely used and is a pivotal element in administrative law. However, EU regulations also use the "broad" and "narrow" concepts of public administration (Kravtsova \& Solonar, 2010; Pukhtetska, 2006). However, quite often in the achievements of European scientists the concept of "public administration" is used to refer to a set of organizational actions, activities, and measures performed by various entities, bodies, and institutions based on the law and within the forms defined by the law to achieve public interest (Beno, 2006).

At present, the national administrative-legal doctrine does not formulate a single approach to defining the system of subjects of public administration in Ukraine. However, studying the theory of public administration as a complex phenomenon and carefully considering the functional and organizational and structural dimensions of public administration, it can be argued that, depending on the scope of public tasks and goals, the system of public administration entities and its constituent elements will have "variational" differences. We must not forget that today's realities are such that functionally the powers of public administration (i.e. public administering) are exercised not only by the executive and local self-government bodies but also by bodies that do not belong to them (Klimova, 2017).

Taking into account the "broad" concept of interpretation of the essence of public administration, among the constituent elements of the system of legal entities who are responsible for performing the functions of the public administration in Ukraine, it is necessary, first of all, to distinguish: bodies of state executive power; executive bodies of local self-government; state institutions, organizations, establishments whose activities are aimed at performing public functions; other entities belonging to the public sector and endowed with public functions.

However, only the executive and local self-government bodies are the bodies of public administration in Ukraine. Although in the system of subjects of public administration of Ukraine every entity acts as an element, so the system of legal actors, which are entrusted with the performance of functions of public administration in Ukraine, is defined as a system.

However, in the systematic characteristics of subjects of public administration in Ukraine, one should also consider the internal content of elements of the system. Because acting within the framework of a single purpose (satisfaction of public interests), the subjects of public administration of Ukraine are organizationally separated, have their own structure, and can be a link of another system. At the same time, the complexities of the public administration system of Ukraine are related to the variability of all elements of the system, the links between them, and the environment in which the administration operates.

\section{Transforming the content of administrative legislation}

The newly formed concept of administrative law also envisages the improvement of normative legal mediation of the principle of the rule of law in the administrative legislation of Ukraine, the analysis of the existing development trends of branch legislation in order to develop practical recommendations for its improvement.

In the context of reforming the field of administrative law of Ukraine, it should be noted that one of the positive aspects of the modern concept of administrative law is the substantial updating and transformation of the content of administrative legislation. First of all, it is about the adoption of the Law of Ukraine "On Administrative Services” as of 06.09.2012 № 5203-VI, the Law of Ukraine "On Prevention of Corruption" as of 14.10.2014 № 1700-VII, the Law of Ukraine "On Civil Service” as of 10.12.2015, № 889-VIII, etc. At the same time, it seems that there are still many problematic issues related to the elimination of divergences, ambiguities, and duplications of the provisions of the current administrative legislation.

\section{Conclusions}

Obviously, from the point of view of the development of the Ukrainian administrative-legal doctrine, the branch of administrative law is in a state of transformation, which is conditioned by the rethinking of values of the state, the priority of ensuring the constitutional rights of citizens. Formation of a fundamentally new theoretical paradigm, the so-called ideology of "humancentrism", tested by most European countries (the socalled European style of government), does not need to develop its principal alternative but only requires taking into account the peculiarities of Ukrainian modernity, which will allow achieving the expected strategic results of realization of various groups of social needs and interests in the basic (fundamental) spheres of public life. Because for now, as a social practice of Ukraine shows, there are significant obstacles to the introduction of the ideology of "human-centrism" not only in the activity of the government machinery but also in the process of formation of a qualitatively new theory of administrative law of Ukraine.

It seems that an integral part of the administrative and legal reform of Ukraine should be the qualitative and substantial updating of the conceptual and categorical framework and, above all, the basic category of "public administration", which requires the development of 
a unified strategy and algorithm for such updating in order to avoid alogism in the functioning of state institutions in the context of Ukraine's European integration.

At the same time, in the context of Ukraine's development as a democratic and legal state, all reform initiatives must be systematic and consistent. Special attention also needs to be paid to scientific and analytical monitoring of the state of introduced changes and consequences of the implemented administrative reform measures, which will allow expeditiously identifying and correcting possible mistakes, as well as making recommendations on further prospects of the development of the administrative and legal sector. Only this approach will help to ensure the guaranteed progressive social development of Ukraine and to bring it to the highest level of social organization and functioning that is characteristic of developed European societies.

\section{References:}

Averianov, V. B. (2002). Administratyvna reforma v Ukraini - stan ta ochikuvannia [Administrative reform in Ukraine - state and expectations]. Administratyvna reforma - istoriia, ochikuvannia ta perspektyvy [Administrative reform - history, expectations, and prospects]. Compiled by V. P. Tymoshchuk. Kyiv : Fakt. (in Ukrainian)

Averianov, V. B. (2003). Reformuvannia ukrainskoho administratyvnoho prava : neobkhidnist pereosmyslennia teoretychnykh postulativ [Reforming Ukrainian administrative law : the need to rethink theoretical postulates]. Aktualni problemy derzhavy i prava [Current Problems of State and Law]. Odesa : Yurydychna Literatura, 19, 6-9. (in Ukrainian)

Averianov, V.B. (2003). Reformuvannia ukrainskoho administratyvnoho prava: gruntovnyi pryvid dlia teoretychnoi dyskusii [Reforming Ukrainian administrative law: a grounded cause for theoretical debate]. Pravo Ukrainy [Law of Ukraine], 5, 117-122. (in Ukrainian)

Averianov, V. B. (1998). Administratyvne pravo Ukrainy: doktrynalni aspekty reformuvannia [Administrative law of Ukraine: doctrinal aspects of reform]. Pravo Ukrainy [Law of Ukraine], 8, 8-13. (in Ukrainian)

Averianov, V.B., \& Pukhtetska,A.A.(2008). Nahalnizavdannia formuvannia ukrainskoi doktrynyadministratyvnoho prava: yevrointehratsiinyi aspekt [The urgent tasks of forming the Ukrainian doctrine of administrative law: the European integration aspect]. Aktualni problemy tlumachennia $i$ zastosuvannia yurydychnykh norm: zbirnyk st. mizhn. nauk.-prakt. konf., prysviachenoi pam iati prof. P.O. Nedbaila [Relevant issues of interpretation and application of legal norms: collection of International Scientific-Practical Conference, dedicated to the memory of prof. P.O. Nedbailo]. Kyiv. (in Ukrainian)

Stetsenko S. H. (Ed.) (2007). Administratyvne pravo Ukrainy: navchalnyi posibnyk [Administrative law of Ukraine: study guide]. Kyiv : Atika. (in Ukrainian)

Andriiko, O. F., Nahrebelnyi, V. P., Kysil, L. Ye., Pedko, Yu. S., Derets, V. A., Pukhtetska, A. A., \& Kirmach, A. V. (2012). Pryntsyp verkhovenstva prava: problemy tlumachennia ta zastosuvannia v administratyvnomu pravi [The rule of law: problems of interpretation and application in administrative law]. Almanakh prava [Almanac of Law], 3, 77-82. (in Ukrainian)

Beno, M. (2006). Vplyv teorii publichnoi administratsii na rozvytok administratyvnoho prava (pryklad Polshchi) [The influence of public administration theory on the development of administrative law (the example of Poland)]. Zakonodavstvo Ukrainy: Naukovo-praktychnyi komentar [Legislation of Ukraine: Scientific-practical commentary], 7, 8-12. (in Ukrainian)

Bilozerska, T. O. (2007). Reformuvannia publichnoi administratsii v Ukraini yak krok do yevropeiskoi intehratsii [Reforming public administration in Ukraine as a step towards European integration]. Forum prava [Forum Prava], 2, 11-19. (in Ukrainian)

Bondarenko, K. (2016). Deiaki aspekty reformy administratyvnoho prava [Some aspects of administrative law reform]. Visegrad Journal on Human Rights, 5/2, 7-11. (in Ukrainian)

Vitvitskyi, S. S. (2016). Kontrol yak harantiia zakonnosti diialnosti publichnoi administratsii [Control as a guarantee of legality of public administration activities]: thesis for Dr. Sc. (Jurisprudence). Kharkiv. (in Ukrainian)

Vlasenko, D. O. (2017). Oskarzhennia rishen, dii chy bezdiialnosti orhaniv publichnoi administratsii z nadannia administratyvnykh posluh [Appeal against decisions, actions or inactivity of public administration bodies for the provision of administrative services]: extended thesis abstract for Cand. Sc. (Jurisprudence). Zaporizhzhia. (in Ukrainian)

Hnydiuk, N. (2006). Vyznachennia poniattia publichnoi administratsii v ACQUIS COMMUNAUTAIRE [Definition of the concept of public administration in ACQUIS COMMUNAUTAIRE]. Zakonodavstvo Ukrainy. Naukovo-praktychni komentari [The legislation of Ukraine. Scientific-practical commentaries], 10, 74-77. (in Ukrainian) Hnydiuk, N. (2001). Publichna administratsiia yak obiekt strukturnykh zmin [Public administration as an object of structural change]. Collection of scientific papers of NAPA; ed. by V.I. Luhovyi, V.M. Kniaziev. Kyiv: Publishing House of NAPA, Iss. 1, pp. 202-212. (in Ukrainian)

Melnyk, R. S. (Ed.) (2014). Zahalne administratyvne pravo: Navchalnyi posibnyk [General administrative law: Study guide]. Kyiv : Vaite. (in Ukrainian)

Kamenska, N.P. (2014).Publichna administratsiia:lohiko-metodolohichnyi analiz definitsii [Public administration: a logical and methodological analysis of the definition]. Naukovi zapysky Instytutu zakonodavstva Verkhovnoi Rady Ukrainy [Scientific Notes of the Institute of Legislation of the Verkhovna Rada of Ukraine], 6, 29-32. (in Ukrainian) 
Karabin, T. O. (2015). Problemy vyznachennia subiektnoho skladu publichnoi administratsii [Problems in determining the subject composition of public administration]. Prykarpatskyi yurydychnyi visnyk [Subcarpathian Law Herald], 3, 164-169. (in Ukrainian)

Kivalov, S. V. (2003). Osnovni napriamky reformuvannia administratyvnoho prava [Main directions of administrative law reform]. Aktualni problemy derzhavy i prava : zbirnyk naukovykh prats [Current Problems of State and Law : collection of scientific papers]. Odesa : Yurydychna Literatura, 19, 3-6. (in Ukrainian)

Klimova, S. M. (2017). Osoblyvosti diialnosti subiektiv publichnoi administratsii u sferi publichnykh finansiv [Features of the activity of public administration entities in the field of public finance]. Problemy zakonnosti [Problems of Legality], 139, 199-210. (in Ukrainian)

Koliushko, I. B., \& Tymoshchuk, V. P. (2005). Reforma publichnoi administratsii v Ukraini: Proekty kontseptsii ta zakoniv [Public administration reform in Ukraine: Draft concepts and laws]. Kyiv. (in Ukrainian)

Kolpakov, V. K. (2008). Predmet administratyvnoho prava : suchasnyi vymir [The subject of administrative law : a modern dimension]. Yurydychna nauka [Legal Science], 3, 33-38. (in Ukrainian)

Kravtsova, T. M., \& Solonar, A. V. (2010). Poniattia ta pryntsypy diialnosti publichnoi administratsii [Concepts and principles of public administration]. Forum Prava, 4, 522-525. (in Ukrainian)

Kolpakov, V. K., Kuzmenko, O. V., Pastukh, I. D., \& Sushchenko, V. D. [et al.] (2012). Kurs administratyvnoho prava Ukrainy: pidruchnyk [Course of Administrative Law of Ukraine : textbook]. Kyiv: Yurinkom Inter. (in Ukrainian)

Mikhrovska, M. S. (2011). Derzhavne upravlinnia ta publichna administratsiia: shliakh do demokratii [Public management and public administration: the way to democracy]. Visnyk Kyivskoho natsionalnoho universytetu imeni Tarasa Shevchenka. Seriia Yurydychni nauky [Bulletin of Taras Shevchenko National University of Kyiv. Series: Legal Sciences], 88, 90-93. (in Ukrainian)

On Administrative Services : Law of Ukraine on 06.09.2012 № 5203-VI. Official Herald of Ukraine. 2012. № 76. Art. 3067. (in Ukrainian)

On Civil Service : Law of Ukraine on 10.12.2015 № 889-VIII. Official Herald of Ukraine. 2016. № 3. Art. 149. (in Ukrainian)

On Prevention of Corruption : Law of Ukraine on 14.10.2014 № 1700-VII. Official Herald of Ukraine. 2014. № 87. Art. 2474. (in Ukrainian)

Pukhtetska, A. A. (2006). «Ievropeiskyi administratyvnyi prostir» yak novela ukrainskoi administratyvnopravovoi nauky: poniatiino-terminolohichna kharakterystyka ["European Administrative Space" as a novel in Ukrainian administrative and legal science: conceptual and terminological characteristics]. Yurydychna Ukraina [Legal Ukraine], 8, 41-45. (in Ukrainian)

Tsvirkun, Yu. I. (2016). Kolehialnist subiektiv publichnoi administratsii [The collegiality of public administration entities]. Naukovyi visnyk Mizhnarodnoho humanitarnoho universytetu. Seriia «Iurysprudentsiia» [Scientific Bulletin of the International Humanitarian University. Series: Jurisprudence], 23, 70-73. (in Ukrainian) 